University of Nebraska - Lincoln

DigitalCommons@University of Nebraska - Lincoln

2000

\title{
Metal exposure in a benthic macroinvertebrate, Hydropsyche californica, related to mine drainage in the Sacramento River
}

Daniel J. Cain

U.S. Geological Survey, djcain@usgs.gov

James L. Carter

U.S. Geological Survey

Steven V. Fend

U.S. Geological Survey

Samuel N. Luoma

U.S. Geological Survey

Charles N. Alpers

U.S. Geological Survey

See next page for additional authors

Follow this and additional works at: https://digitalcommons.unl.edu/usgsstaffpub

Part of the Earth Sciences Commons

Cain, Daniel J.; Carter, James L.; Fend, Steven V.; Luoma, Samuel N.; Alpers, Charles N.; and Taylor, Howard E., "Metal exposure in a benthic macroinvertebrate, Hydropsyche californica, related to mine drainage in the Sacramento River" (2000). USGS Staff -- Published Research. 473.

https://digitalcommons.unl.edu/usgsstaffpub/473

This Article is brought to you for free and open access by the US Geological Survey at DigitalCommons@University of Nebraska - Lincoln. It has been accepted for inclusion in USGS Staff -- Published Research by an authorized administrator of DigitalCommons@University of Nebraska - Lincoln. 


\section{Authors}

Daniel J. Cain, James L. Carter, Steven V. Fend, Samuel N. Luoma, Charles N. Alpers, and Howard E. Taylor 


\title{
Metal exposure in a benthic macroinvertebrate, Hydropsyche californica, related to mine drainage in the Sacramento River
}

\author{
Daniel J. Cain, James L. Carter, Steven V. Fend, Samuel N. Luoma, \\ Charles N. Alpers, and Howard E. Taylor
}

\begin{abstract}
A biomonitoring technique was employed to complement studies of metal transport in the upper Sacramento River affected by acid mine drainage. Metals ( $\mathrm{Al}, \mathrm{Cd}, \mathrm{Cu}, \mathrm{Fe}, \mathrm{Hg}, \mathrm{Pb}$, and $\mathrm{Zn}$ ) were determined in a resident invertebrate, Hydropsyche californica (Insecta: Trichoptera), and streambed sediments $(<62 \mu \mathrm{m})$ to assess metal contamination within a $111-\mathrm{km}$ section of the river downstream of the mining area. Metals in $H$. californica also were interpreted to be broadly indicative of metal exposure in fish. Total $\mathrm{Hg}$ was determined in the whole body of the insect, whereas $\mathrm{Al}$, $\mathrm{Cd}, \mathrm{Cu}, \mathrm{Fe}, \mathrm{Pb}$, and $\mathrm{Zn}$ were additionally separated into operationally defined cytosolic (used as an indicator of exposure to bioavailable metal) and particulate fractions. Total concentrations of $\mathrm{Cd}, \mathrm{Cu}, \mathrm{Hg}, \mathrm{Pb}$, and $\mathrm{Zn}$ in sediments were consistent with documented upstream sources of acid mine drainage. Metal distribution patterns in H. californica and sediments were generally consistent for $\mathrm{Cd}, \mathrm{Cu}$, and $\mathrm{Pb}$ but inconsistent for $\mathrm{Hg}$ and $\mathrm{Zn}$. Concentrations in H. californica indicated that bioavailable $\mathrm{Cd}, \mathrm{Cu}, \mathrm{Pb}$, and $\mathrm{Zn}$ was transported at least $120 \mathrm{~km}$ downstream of the mine sources. Zinc in $H$. californica was elevated, but unlike sediments, did not decrease downstream. Mercury in H. californica was not elevated.
\end{abstract}

\begin{abstract}
Résumé : Une technique de biosurveillance a été utilisée pour compléter des études sur le transport de métaux dans le cours supérieur de la rivière Sacramento contaminée par l'eau d'exhaure acide. Les métaux ( $\mathrm{Al}, \mathrm{Cd}, \mathrm{Cu}, \mathrm{Fe}, \mathrm{Hg}, \mathrm{Pb}$ et Zn) ont été mesurés chez un invertébré résident, Hydropsyche californica (Insecta : Trichoptera), et dans les sédiments du lit $(<62 \mu \mathrm{m})$ afin d'évaluer la contamination par les métaux dans un tronçon de $111 \mathrm{~km}$ de la rivière en aval de la région minière. La présence de métaux chez $H$. californica a aussi été interprétée comme une indication générale d'une exposition des poissons à ces métaux. La concentration totale de $\mathrm{Hg}$ a été mesurée dans tout le corps des insectes, tandis que $\mathrm{Al}, \mathrm{Cd}, \mathrm{Cu}, \mathrm{Fe}, \mathrm{Pb}$ et $\mathrm{Zn}$ ont en outre été séparés en fractions cytolosique (utilisée comme indicateur de l'exposition au métal biodisponible) et particulaire définies opérationnellement. Les concentrations totales de $\mathrm{Cd}, \mathrm{Cu}$, $\mathrm{Hg}, \mathrm{Pb}$ et $\mathrm{Zn}$ dans les sédiments concordaient avec l'information connue sur les sources d'eau d'exhaure acide en amont. Les profils de répartition des métaux chez $H$. californica et dans les sédiments étaient en général cohérents dans les cas du $\mathrm{Cd}$, du $\mathrm{Cu}$ et du $\mathrm{Pb}$, mais irréguliers dans le cas de $\mathrm{Hg}$ et de $\mathrm{Zn}$. Les concentrations chez H. californica ont montré que le $\mathrm{Cd}$, le $\mathrm{Cu}$, le $\mathrm{Pb}$ et le $\mathrm{Zn}$ biodisponibles étaient transportés à au moins $120 \mathrm{~km}$ en aval des sources minières. La concentration de $\mathrm{Zn}$ chez $H$. californica était élevée, mais à la différence de ce qu'on observait dans les sédiments, elle ne diminuait pas en aval. La concentration de $\mathrm{Hg}$ chez $H$. californica n'était pas élevée.
\end{abstract}

[Traduit par la Rédaction]

\section{Introduction}

Metal contamination of freshwaters by mining is widespread (Moore and Luoma 1990). While total metal concentrations in environmental media (e.g., water and sediment) indicate the relative degree and extent of contamination, they

Received March 2, 1999. Accepted September 24, 1999. $\mathrm{J} 15040$

D.J. Cain, ${ }^{1}$ J.L. Carter, S.V. Fend, and S.N. Luoma. U.S. Geological Survey, MS 465, 345 Middlefield Road, Menlo Park, CA 94025, U.S.A.

C.N. Alpers. U.S. Geological Survey, 6000 J Street,

Placer Hall, Sacramento, CA 95819-6129, U.S.A.

H.E. Taylor. U.S. Geological Survey, 3215 Marine Street, Boulder, CO 80303, U.S.A.

${ }^{1}$ Author to whom all correspondence should be addressed. e-mail: djcain@usgs.gov do not necessarily reflect exposures in resident fauna. Benthic insects are one group of organisms used to monitor metal exposures and assess biological effects in freshwaters (Cain et al. 1992; Hare 1992; Rosenberg and Resh 1993). Assessments of biological risk associated with exposure are strengthened when methods allow distinction between metal that is taken up and accumulated within cells and metal that occurs extracellularly. The latter includes a variety of forms that probably pose little toxic risk (e.g., metals or metalbearing particles on external body parts and metals retained with undigested material in the gut of the animal). Recently, Cain and Luoma (1998) evaluated metal exposures in a miningimpacted river by determining metal concentrations of the cytosol (the soluble portion of the cell cytoplasm) in an aquatic insect.

Metals analysis of the cytosol and (or) other intracellular components provides an unambiguous indicator of metal bioavailability. The cytosol appears to be an important accumu- 
lation site for essential metals such as $\mathrm{Cu}$ and $\mathrm{Zn}$ and certain nonessential elements, including Cd (Seidman et al. 1986; Cain and Luoma 1998; Suzuki et al. 1988). Furthermore, sublethal effects have been shown to coincide with a redistribution of $\mathrm{Cd}$ among cytosolic ligands that occurs with increasing Cd accumulation (Jenkins and Mason 1988). Therefore, concentrations of cytosolic metals reflect intracellular dose and may be a better diagnostic of toxicity than either whole-body or whole-tissue concentrations (Thorpe and Costlow 1989; Roesijadi 1994).

Cytosolic metal also appears to be a biologically available component of food. Reinfelder and Fisher (1991) demonstrated that the efficiency of metal absorption by copepods fed metal-contaminated algae was directly proportional to metal in the cytosolic fraction of the algae. Although such simple relationships are not always observed (Lee and Luoma 1998), studies with predators and their prey suggest that the cytosolic metal fraction is one component of dietary exposure (Reinfelder and Fisher 1994; Wallace and Lopez 1997). In contrast, metals that are encased in intracellular inclusions, such as $\mathrm{Ca}$ or phosphate-rich granules, are not efficiently digested by predators and are passed intact through the digestive tract (Nott and Nicolaidou 1990). Similarly, other particulate forms of metal that reside outside the cell, such as those sorbed to external body parts and bound to undigested gut content, may be largely unavailable to higher trophic organisms.

The upper Sacramento River is affected by acid mine drainage. Metal contamination of the aquatic food web has been documented (Wilson et al. 1981; Saiki et al. 1995), but the downstream extent of metal contamination has not been fully resolved, and little is specifically known about the biological availability of metals within the river. The upper Sacramento River is of special concern because it includes spawning ground for several salmonid fish species, including four distinct runs of chinook salmon (Oncoryhnchus tshawytscha), steelhead trout (Oncorhynchus mykiss), and resident rainbow trout (O. mykiss) (U.S. Environmental Protection Agency 1992). The winter-run chinook salmon is a federally listed endangered species, and the steelhead trout and one or more of the other chinook salmon runs have recently been listed as threatened species (National Oceanic and Atmospheric Administration 1994, 1997).

This study was one component of a multidisciplinary study of the distribution, transport, and fate of metals in the Sacramento River. Detailed studies specific to metal geochemistry and transport are reported elsewhere (Alpers et al. 1999). Here, the principal objective was to assess the occurrence and distribution of biologically available metals in the upper Sacramento River, relative to sediment metal contamination, downstream of documented sources of acid mine drainage. Also, because of the concern for resident fish, there was a need for data that were at least broadly indicative of dietary metal exposure in fish.

To satisfy our objectives, metal concentrations were determined in larvae of the hydropsychid caddisfly Hydropsyche californica. The genus Hydropsyche is widely distributed and abundant in many rivers, including the Sacramento River. The larva lives for about 1 year as a sedentary, omnivorous filter-feeder. Therefore, metal concentrations in the larva are site specific, and the period of exposure is on the order of 1 year or less. Larvae of Hydropsyche are relatively metal tolerant (Spehar et al. 1978; Clements et al. 1992), thereby making them a good organism for monitoring metal contamination (Cain et al. 1992). Consumption of metalcontaminated benthic macroinvertebrates, such as Hydropsyche, can be a significant cause of chronic metal contamination in resident trout (Farag et al. 1995; Woodward et al. 1995), although studies to identify the form(s) of metal absorbed during digestion have not been conducted. We suggest that an analysis of the metal partitioning in prey species of fish may help identify metals most likely to be accumulated from food.

\section{Methods}

\section{Site description}

Drainage from base-metal mines at Iron Mountain has been a principal source of metals to the Sacramento River in northern California that has threatened resident fauna for many years (Finlayson and Verrue 1980; Wilson et al. 1981; National Oceanic and Atmospheric Administration 1989). Recurring fish kills instigated the construction of the Spring Creek Debris Dam (SCDD) in 1963 to reduce the discharge of metal-laden acid mine water from Spring Creek into the Sacramento River (Fig. 1). In addition, water is treated with lime to precipitate metals. A temporary limeneutralization plant operated 3-4 months per year during 19891993. Since July 1994, there has been continuous, year-round treatment. Treatment has reduced annual metal loadings of $\mathrm{Cu}$ by about $80-85 \%$ and $\mathrm{Zn}$ (and probably $\mathrm{Cd}$ also) by about $90 \%$. Prior to lime-neutralization treatment, about $90 \%$ of the $\mathrm{Cu}$ loading to the Sacramento River at Keswick Dam could be attributed to Spring Creek and the Iron Mountain mine drainage (D. Heiman, State of California Regional Water Quality Control Board, Sacramento, Calif., unpublished data). Since 1994, this component of the overall $\mathrm{Cu}$ loading has been reduced to about $50 \%$. The remainder is predominantly from other mines in the West Shasta mining district that drain into Shasta Lake via Little Backbone Creek and West Squaw Creek (D. Heiman, unpublished data).

Flows from the SCDD are regulated by the Bureau of Reclamation, together with dilution flows from Shasta Lake and Whiskeytown Lake (via the Spring Creek Power Plant), to meet water quality criteria for the protection of resident fish at a compliance point below Keswick Dam (Fig. 1). Nevertheless, these water quality criteria are periodically exceeded during periods of heavy rainfall when water in the Spring Creek Reservoir overtops the SCDD and insufficient dilution flows are available.

\section{Sample collection}

Hydropsyche larvae were collected at five stations in the Sacramento River within a 111-km section between Rodeo Park near Redding (river km 479) and Tehama (river km 368) (Fig. 1). Station locations were determined by the availability of suitable habitat and proximity to stations where water quality data were collected for related studies of metal transport. High seasonal flows and managed releases of water from Shasta Dam prohibited sampling during much of the year. Samples for this study were collected during October 21-23, 1996, coincident with seasonal lows in discharge, sediment transport, and metal loading. In addition, a sample was collected from Cottonwood Creek, near Cottonwood (river km 439) (Fig. 1), and used as a local reference to evaluate metal levels in samples from the Sacramento River.

At each station, Hydropsyche larvae were collected from a single, shallow ( $<0.5 \mathrm{~m}$ deep) riffle using large kick nets constructed of cotton mesh (approximately 1-mm mesh size) and plastic (PVC) handles. Specimens were picked from the net with nylon forceps 
Fig. 1. Names, numerical designations, and locations of stations in the upper Sacramento River and Cottonwood Creek where H. californica and sediments were collected in October 1996.

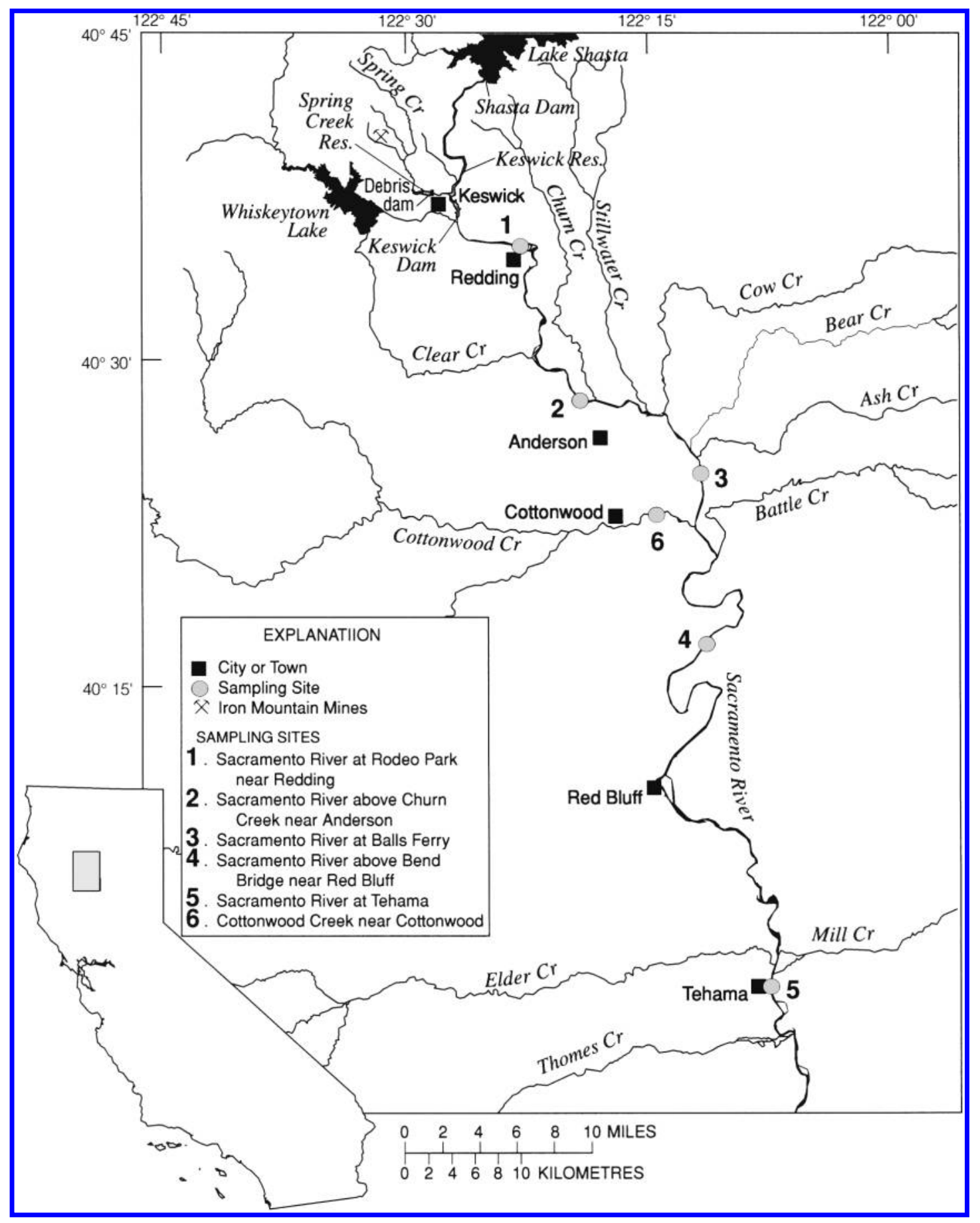

and placed into plastic trays with stream water (forceps and trays were previously acid washed). Water in the trays was freshened periodically. Specimens were transferred from the trays to plastic, sealed bags and frozen on dry ice in a small volume of river water within $1 \mathrm{~h}$ of collection. The field collections were moved to the laboratory where they were stored at $-70^{\circ} \mathrm{C}$ until sample preparation. Specimens for taxonomic identification were preserved in $10 \%$ formalin in the field and transferred to $75 \%$ ethanol in the laboratory. Collections contained a single species, $H$. californica.

\section{Sample preparation}

Samples for the determination of $\mathrm{Al}, \mathrm{Cd}, \mathrm{Cu}, \mathrm{Fe}, \mathrm{Pb}$, and $\mathrm{Zn}$ were prepared following the method described by Cain and Luoma (1998). Specimens collected from a station were partially thawed in batches, rinsed with cold deionized water to remove sediment and detritus, and then transferred to a glass sorting dish that was placed on a bed of ice. The animals were immersed in a small amount of water and viewed individually under a stereomicroscope for identification and further cleaning. Hydropsyche californica were collected for metals analysis. Instars were not sorted, although smaller specimens that could not be identified were discarded. Specimens were then transferred to a cooler. When the entire sample had been sorted and cleaned (1-2 h), the animals were blotted dry with tissue paper, pooled into replicate, composite 
samples $(n=4-6)$ of approximately the same wet weight, and then temporarily refrigerated.

Cold $0.05 \mathrm{M}$ Tris- $\mathrm{HCl}$ buffer ( $\mathrm{pH} 7.4$, previously degassed and bubbled with $\mathrm{N}_{2}$ ) was added to each sample at a ratio of 8:1 (millilitres of Tris per gram wet weight of subsample). Samples were homogenized with a stainless steel high-speed tissue homogenizer under a nitrogen atmosphere for $1 \mathrm{~min}$. The homogenate was subsampled for two fractions: one for the whole-body metal analysis and the other for the cytosolic metals. The cytosol was isolated by centrifuging the homogenate at $100000 \times g$ for $1 \mathrm{~h}$ at $5^{\circ} \mathrm{C}$. The supernatant (cytosol) and pellet were collected and transferred to separate screw-cap glass vials. Samples were kept cold throughout the procedure. Sample fractions were frozen at $-20^{\circ} \mathrm{C}$ as they were prepared. Later, they were freeze-dried, weighed, and digested by reflux in hot, isopiestically distilled $16 \mathrm{~N} \mathrm{HNO}_{3}$. When the digestion was complete, the samples were evaporated to dryness.

Prior to analysis, sample residues were reconstituted by the addition of $10 \mathrm{~mL}$ of $1 \%$ high-purity $\mathrm{HNO}_{3}$. Five millilitres of this solution was diluted to $50 \mathrm{~mL}$ for trace metal analysis.

All plastic and glassware used for sample preparation was cleaned by soaking overnight in a Micro ${ }^{\circledR 2}$ solution, rinsed with deionized water, and then washed in either $10 \% \mathrm{HCl}$ or $10 \% \mathrm{HNO}_{3}$ and rinsed with deionized water. The tissue homogenizer was cleaned by soaking overnight in a solution of $\mathrm{RBS}^{\circledR}$ and rinsed in deionized water.

Total $\mathrm{Hg}$ concentrations were determined in the whole body only to assess the occurrence of $\mathrm{Hg}$ contamination. Additional samples from all stations were sorted and cleaned as described above. Station samples were composed of single or duplicate composites, which were immediately frozen at $-20^{\circ} \mathrm{C}$. The composites were freezedried and then homogenized with a mixer mill using $125-\mathrm{mL}$ polycarbonate jars and methacrylate balls. Samples were digested following the procedure described by Elrick and Horowitz (1986).

\section{Streambed sediments}

Streambed sediment was collected from three to six depositional areas within $100 \mathrm{~m}$ at each station following procedures developed for the U.S. Geological Survey's National Water Quality Assessment Program (Shelton and Capel 1994). The sediment was scooped from the surface $(<1 \mathrm{~cm}$ depth) with an acid-washed plastic spatula and composited into an acid-washed 8-L container. The sediment and associated river water were homogenized and then sieved through a $62-\mu \mathrm{m}$ nylon mesh. The sediment passing through the mesh was collected in acid-washed, plastic screw-cap jars and then chilled on ice for transport to the laboratory. Sediments were transferred to a freezer $\left(-5^{\circ} \mathrm{C}\right)$ until further processing. The sediment was freeze-dried for $24 \mathrm{~h}$, weighed, and then digested in a microwave with a mixture of $\mathrm{HCl}, \mathrm{HNO}_{3}$, and $\mathrm{HF}$. Prior to analysis, $\mathrm{H}_{3} \mathrm{BO}_{3}$ was added to the solutions to complex excess fluoride.

\section{Metals analysis}

Metals were determined using several different techniques. Aluminum, $\mathrm{Cd}, \mathrm{Cu}, \mathrm{Pb}$, and $\mathrm{Zn}$ were determined on the digested samples by inductively coupled plasma - mass spectrometry using a modification of a direct analysis procedure (Taylor and Garbarino 1991). Iron was determined by a modified inductively coupled plasma - atomic emission spectrometric technique (Taylor and Garbarino 1985) at a wavelength of $259.94 \mathrm{~nm}$. Mercury in the caddisflies was determined by cold-vapor atomic absorption spectrophotometry using conditions described by Elrick and Horowitz (1986). Mercury in streambed sediments was determined by automated cold-vapor atomic fluorescence as described by Roth (1994).

\section{Quality assurance}

Laboratory determinations of $\mathrm{Al}, \mathrm{Cd}, \mathrm{Cu}, \mathrm{Fe}, \mathrm{Pb}$, and $\mathrm{Zn}$ were performed in triplicate on each composite sample. Single or duplicate determinations of $\mathrm{Hg}$ were performed. Standard deviations reported for concentrations of each station represent the combined precisions associated with sample collection, processing, and analysis of the composite samples.

Accuracy was established by the analysis of standard reference materials obtained from the National Institute of Standards and Technology (NIST) and the National Research Council of Canada (NRC). Four materials were selected to simulate invertebrate tissue: NIST SRM 1566a (oyster tissue), NIST SRM50 (albacore tuna), NRC Tort-2 (lobster hepatopancreas), and NRC Dorm-2 (dogfish muscle). NIST 2704 (Buffalo River sediment) was used for streambed sediments. Standards were processed in a manner identical to the procedure used for the samples. The medians of the observed concentrations for the analysis of the biological reference materials ranged from 92 to $105 \%$ of the reported concentrations except for $\mathrm{Al}(68 \%)$ and $\mathrm{Pb}$ in SRM 50 (120\%). In addition, selected representative caddisfly samples were spiked with a standard containing $\mathrm{Cd}, \mathrm{Cu}, \mathrm{Pb}$, and $\mathrm{Zn}$ prior to sample processing to establish their recovery during sample handling and analysis. The median (and range) of spike recoveries was 98\% (95-102) for Cd, 94\% (82-100) for $\mathrm{Cu}, 93 \%$ (87-98) for $\mathrm{Pb}$, and 96\% (93-108) for $\mathrm{Zn}$. Median recoveries of total digests of NIST 2704 ranged from 93 to $107 \%$ of the certified concentrations.

Procedural and reagent blanks were analyzed to evaluate potential contamination problems during sample processing and analysis. Appropriate reagent blank concentration values were used to correct the chemical analyses where necessary.

\section{Data analysis}

Metal concentrations in streambed sediments are reported as the mean and standard deviation $(n=3)$. The mean, standard deviation, and standard error of composite caddisfly samples $(n=4-6$ for all samples except those analyzed for $\mathrm{Hg}$ where $n=1$ or 2) from each station are reported. The number of samples generally reflected the abundance of $H$. californica at each station. Tissue enrichment factors were calculated by dividing the mean metal concentrations of stations in the Sacramento River by the mean metal concentrations of the sample from Cottonwood Creek. The percentage of metal recovered in the cytosol was calculated by dividing the metal concentration of the cytosol by the whole-body metal concentration and multiplying the result by 100 . Differences in metal concentrations among stations were determined by single-classification ANOVA, after the data were log transformed to correct for heteroscedasticity. Specific station comparisons were analyzed by the Turkey honest significant differences test for unequal sample sizes. Data that were not corrected by log transformation were analyzed by the Kruskal-Wallis ANOVA. Pearson product-moment correlations were determined between whole-body, particulate, and cytosolic metal concentrations using the mean sample concentrations to avoid any bias due to unequal sample sizes (even though withinstation variance was much less than among-station variance). Correlation analysis also was done between metal concentrations in Hydropsyche and streambed sediments. Interelement correlations were performed separately on tissue and sediment metal concentrations among stations to assess similarities in the spatial distributions of metals within each type of sample. Results of statistical tests were considered significant if $\alpha<0.05$.

\section{Results}

\section{Metal enrichment in Hydropsyche}

Mean concentrations of $\mathrm{Cd}, \mathrm{Cu}, \mathrm{Pb}$, and $\mathrm{Zn}$ in the whole body, pellet, and cytosol of Hydropsyche from all stations in

\footnotetext{
${ }^{2}$ Any use of trade, product, or firm names is for descriptive purposes only and does not imply endorsement by the U.S. Government.
} 
Table 1. Metal concentrations $\left(\mu \mathrm{g} \cdot \mathrm{g}\right.$ dry weight ${ }^{-1}$ ) in $H$. californica collected from the Sacramento River and Cottonwood Creek during October 21-23, 1996.

\begin{tabular}{|c|c|c|c|c|c|c|c|c|}
\hline \multirow[b]{2}{*}{ Element } & \multirow[b]{2}{*}{$\begin{array}{l}\text { Body } \\
\text { fraction }\end{array}$} & \multicolumn{6}{|l|}{ Station } & \multirow[b]{2}{*}{ EF } \\
\hline & & $\begin{array}{l}1 \text { (Rodeo } \\
\text { Park) }\end{array}$ & $\begin{array}{l}2 \text { (Churn } \\
\text { Creek) }\end{array}$ & $\begin{array}{l}3 \text { (Balls } \\
\text { Ferry) }\end{array}$ & $\begin{array}{l}4 \text { (Bend } \\
\text { Bridge) }\end{array}$ & $\begin{array}{l}5 \\
\text { (Tehama) }\end{array}$ & $\begin{array}{l}6 \text { (Cottonwood } \\
\text { Creek) }\end{array}$ & \\
\hline \multirow{2}{*}{$\mathrm{Al}$} & Cytosol & $10 \pm 1$ & $8 \pm 0.4$ & $11 \pm 2$ & $6 \pm 1$ & $6 \pm 1$ & $3 \pm 0.4$ & $2.0-3.7$ \\
\hline & Pellet & $960 \pm 150$ & $1420 \pm 87$ & $1270 \pm 80$ & $1720 \pm 130$ & $1710 \pm 80$ & $1130 \pm 110$ & $0.8-1.5$ \\
\hline $\mathrm{Cd}$ & Whole body & $2.16 \pm 0.10$ & $0.96 \pm 0.05$ & $0.77 \pm 0.08$ & $1.14 \pm 0.09$ & $0.66 \pm 0.02$ & $0.06 \pm 0.02$ & $11-36$ \\
\hline \multirow[t]{3}{*}{$\mathrm{Cu}$} & Whole body & $37.5 \pm 3.2$ & $37.7 \pm 1.6$ & $25.0 \pm 1.3$ & $30.8 \pm 2.5$ & $25.6 \pm 1.2$ & $14.5 \pm 0.4$ & $1.7-2.6$ \\
\hline & Cytosol & $20.7 \pm 1.1$ & $20.8 \pm 1.0$ & $14.1 \pm 0.3$ & $16.8 \pm 1.3$ & $12.1 \pm 0.9$ & $6.9 \pm 0.4$ & $1.8-3.0$ \\
\hline & Pellet & $15.3 \pm 6.0$ & $18.4 \pm 1.3$ & $12.1 \pm 0.8$ & $16.2 \pm 1.3$ & $14.0 \pm 0.6$ & $7.8 \pm 0.6$ & $1.6-2.4$ \\
\hline \multirow[t]{2}{*}{$\mathrm{Fe}$} & Whole body & $1460 \pm 150$ & $2070 \pm 50$ & $1340 \pm 320$ & $1970 \pm 590$ & $2830 \pm 190$ & $1860 \pm 200$ & $0.7-1.5$ \\
\hline & Cytosol & $45 \pm 2$ & $57 \pm 9$ & $65 \pm 5$ & $78 \pm 8$ & $55 \pm 7$ & $69 \pm 10$ & $0.7-1.1$ \\
\hline $\mathrm{Pb}$ & Pellet & $1.06 \pm 0.46$ & $1.08 \pm 0.07$ & $0.88 \pm 0.19$ & $1.02 \pm 0.05$ & $1.05 \pm 0.05$ & $0.52 \pm 0.02$ & $1.7-2.1$ \\
\hline \multirow[t]{3}{*}{$\mathrm{Zn}$} & Whole body & $169 \pm 9$ & $160 \pm 4$ & $171 \pm 4$ & $208 \pm 6$ & $160 \pm 5$ & $113 \pm 6$ & $1.4-1.8$ \\
\hline & Cytosol & $82 \pm 3$ & $96 \pm 5$ & $95 \pm 3$ & $104 \pm 4$ & $80 \pm 5$ & $59 \pm 5$ & $1.4-1.8$ \\
\hline & Pellet & $87 \pm 17$ & $101 \pm 3$ & $91 \pm 8$ & $108 \pm 5$ & $94 \pm 3$ & $58 \pm 5$ & $1.5-1.9$ \\
\hline
\end{tabular}

Note: Values are the mean \pm 1 SD $(n=1-6)$. Metal enrichment factors (EF) in the Sacramento River (metal concentration of Sacramento River station/metal concentration in Cottonwood Creek) are shown. NE, not enriched (i.e., EF < 1).

the Sacramento River were significantly greater than in those from Cottonwood Creek, the reference site (Table 1). Aluminum concentrations in the cytosol also were consistently higher in samples from the Sacramento River; however, concentrations in the whole body (and pellet) were not significantly different from those in the Cottonwood Creek sample. Iron concentrations in all body fractions in Sacramento River samples were variable but were not either uniformly higher or lower than concentrations in the Cottonwood Creek sample. Mercury concentrations in samples from the Sacramento River were $\leq 0.06 \mu \mathrm{g} \cdot \mathrm{g}^{-1}$ and lower than the concentration in the sample from Cottonwood Creek. Among the metals analyzed, Cd showed the greatest degree of enrichment, regardless of body fraction. Enrichment factors for other metals in the whole body and pellet followed the order $\mathrm{Cu}>\mathrm{Pb}>\mathrm{Zn}>\mathrm{Al}$. Relative to Cottonwood Creek, $\mathrm{Al}$ and $\mathrm{Pb}$ were more enriched in the cytosol than in the whole body, and therefore, the order of enrichment was $\mathrm{Cd}>\mathrm{Pb}>\mathrm{Al} \geq \mathrm{Cu}>\mathrm{Zn}$.

\section{Metal partitioning in the insect}

Whole-body concentrations represent the accumulation of both cytosolic and noncytosolic, particulate metal forms. (Particulate metal forms are operationally defined as metal retained in the pellet after ultracentrifugation.) Partitioning between cytosolic and particulate forms differed greatly among different groups of elements. The cytosol was an important accumulation site for $\mathrm{Cd}, \mathrm{Cu}$, and $\mathrm{Zn}$, accounting for approximately $50-100 \%$ of the total body burden of these elements (Table 2). Much lower percentages $(\leq 20 \%)$ of the body burdens of $\mathrm{Al}, \mathrm{Fe}$, and $\mathrm{Pb}$ occurred in the cytosol (Table 2). Particulate form(s) accounted for more than $99 \%$ of the total $\mathrm{Al}$ body burden and at least $85 \%$ of the total $\mathrm{Fe}$ body burden. The proportion of particulate $\mathrm{Pb}$ ranged between 80 and $92 \%$.

As expected, the results of correlations between the wholebody and cytosolic and particulate metal concentrations were affected by partitioning of metal in the insect. Because the cytosol was a major accumulation site for $\mathrm{Cd}, \mathrm{Cu}$, and $\mathrm{Zn}$, cytosolic concentrations of these metals correlated strongly with whole-body concentrations (Fig. 2), and therefore, wholebody $\mathrm{Cd}, \mathrm{Cu}$, and $\mathrm{Zn}$ concentrations were indicative of exposures to biologically available metal. Concentrations in the particulate fraction, which represented up to $53 \%$ of the body burden, also correlated with the whole-body concentrations (results not shown). Aluminum and Fe concentrations in the whole body did not correlate with cytosolic $\mathrm{Al}$ and $\mathrm{Fe}$ concentrations. Whole-body and cytosolic concentrations of Al were negatively correlated among stations in the Sacramento River ( $p=0.04$ ) (Fig. 2). Cytosolic Fe concentrations were independent of whole-body concentrations. A weak, positive relationship between whole-body and cytosolic $\mathrm{Pb}$ was influenced by the low concentrations in the Cottonwood Creek sample (Fig. 2). Among samples from the Sacramento River, whole-body $\mathrm{Pb}$ concentrations were not predictive of cytosolic $\mathrm{Pb}$ concentrations (Fig. 2). For $\mathrm{Al}, \mathrm{Fe}$, and $\mathrm{Pb}$, concentrations in the whole body and particulate fraction were highly correlated ( $p \leq 0.02$ ), reflecting the dominant accumulation of these elements in noncytosolic forms.

Spatial patterns in whole-body concentrations of $\mathrm{Al}$, Fe, $\mathrm{Pb}$, and $\mathbf{H g}$

As suggested above, spatial patterns in the concentrations of $\mathrm{Al}, \mathrm{Fe}$, and $\mathrm{Pb}$ in the whole body (and the particulate 
Table 2. Mean percentage of total metal body burden recovered in the cytosol (calculated as cytosolic metal concentration/whole body metal concentration $\times 100$ ) of $H$. californica collected from the Sacramento River and Cottonwood Creek.

\begin{tabular}{|c|c|c|c|c|c|c|}
\hline \multirow[b]{2}{*}{ Element } & \multicolumn{6}{|l|}{ Station } \\
\hline & 1 (Rodeo Park) & 2 (Churn Creek) & 3 (Balls Ferry) & 4 (Bend Bridge) & 5 (Tehama) & 6 (Cottonwood Creek) \\
\hline $\mathrm{Al}$ & 0.8 & 0.6 & 0.8 & 0.3 & 0.3 & 0.2 \\
\hline $\mathrm{Cd}$ & 59 & 57 & 68 & 64 & 55 & 100 \\
\hline $\mathrm{Cu}$ & 55 & 55 & 56 & 55 & 47 & 48 \\
\hline $\mathrm{Fe}$ & 3 & 3 & 5 & 4 & 2 & 4 \\
\hline $\mathrm{Pb}$ & 20 & 12 & 19 & 17 & 12 & 8 \\
\hline $\mathrm{Zn}$ & 49 & 60 & 56 & 50 & 50 & 52 \\
\hline
\end{tabular}

Fig. 2. Correlation between the mean metal concentrations in the whole body and cytosol of $H$. californica. Data are identified by station. (a) $\mathrm{Al} ;(b) \mathrm{Fe} ;(c) \mathrm{Pb} ;(d) \mathrm{Cd} ;(e) \mathrm{Cu} ;(f) \mathrm{Zn}$. The correlation coefficient $r$ and probability level $p$ are given for each element. Data are fitted using a linear regression. Dotted lines are the $95 \%$ confidence intervals.
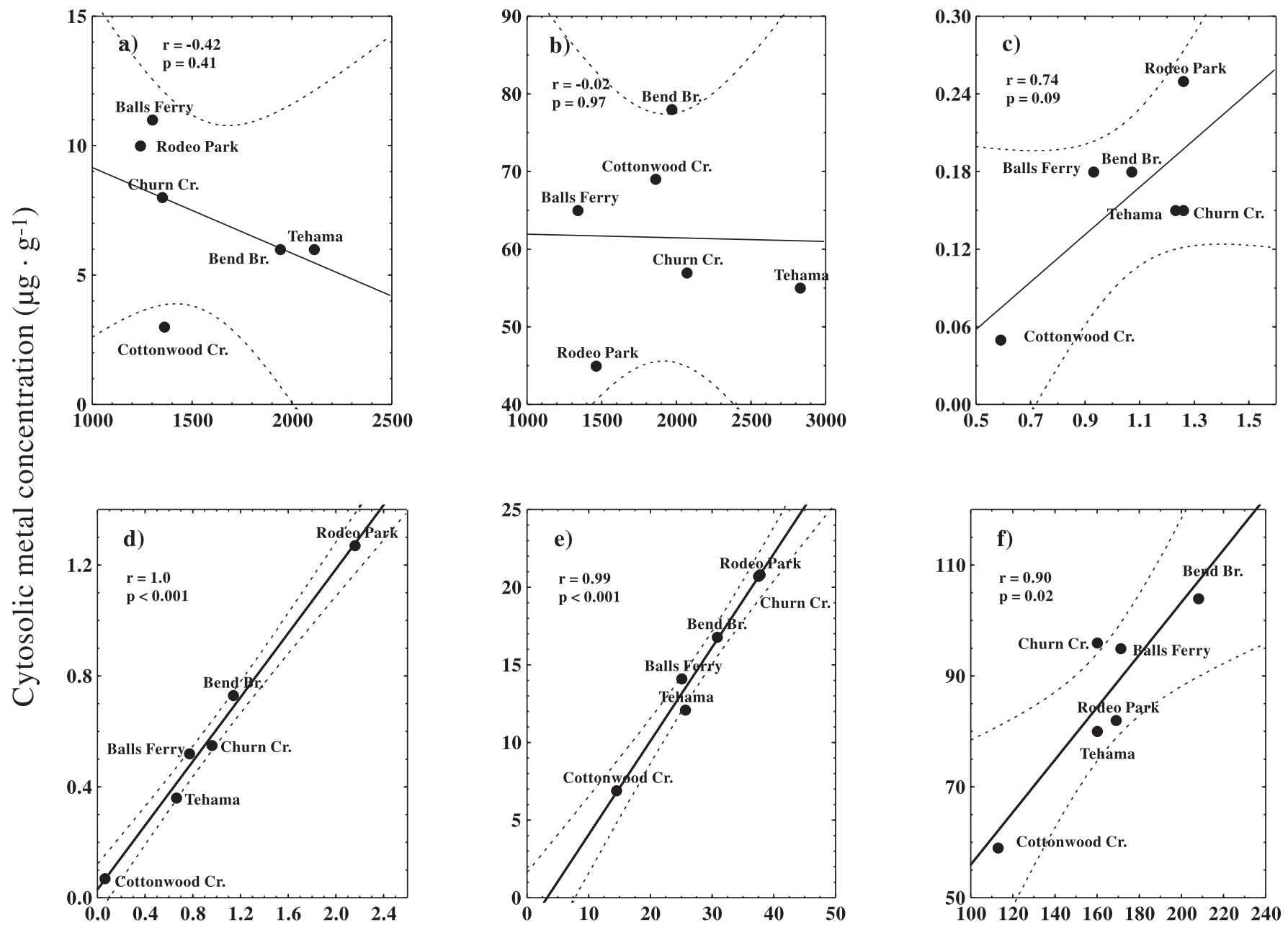

Whole-body metal concentration $\left(\mu \mathrm{g} \cdot \mathrm{g}^{-1}\right)$

fraction) were distinctly different from those displayed in the cytosol. Whole-body concentrations of Al and Fe exhibited similarities in their longitudinal distribution within the Sacramento River that differed from the distributions of other elements. Concentrations between Rodeo Park and Balls Ferry (stations 1-3) were generally lower than concentrations at Bend Bridge (station 4) and Tehama (station 5) (Fig. 3). Between Balls Ferry and Tehama, concentrations of
$\mathrm{Al}$ and $\mathrm{Fe}$ in the whole body increased significantly. Lead concentrations were highest at Rodeo Park, Churn Creek, and Tehama (Fig. 3). Thus, there was no net change in $\mathrm{Pb}$ concentration between the most upstream and downstream stations, but concentrations decreased significantly between Churn Creek and Balls Ferry and then progressively increased downstream to Tehama. The concentration pattern of $\mathrm{Pb}$ between Balls Ferry and Tehama closely resembled 
Fig. 3. Metal concentrations in the whole body and cytosol of $H$. californica from stations in the upper Sacramento River and Cottonwood Creek (metal reference site). Stations in the Sacramento River are numbered sequentially (1-5) from upstream to downstream, as described in Fig. 1. Station 6 is Cottonwood Creek. (a) $\mathrm{Al} ;(b) \mathrm{Fe} ;(c) \mathrm{Pb} ;(d) \mathrm{Cd} ;(e) \mathrm{Cu}$; $(f) \mathrm{Zn}$. Note the scale breaks for the concentrations of $\mathrm{Al}, \mathrm{Fe}$, and $\mathrm{Pb}$. Values are the mean $\pm 1 \mathrm{SE}$ (shaded box) and the mean $\pm 1 \mathrm{SD}$ (whiskers).
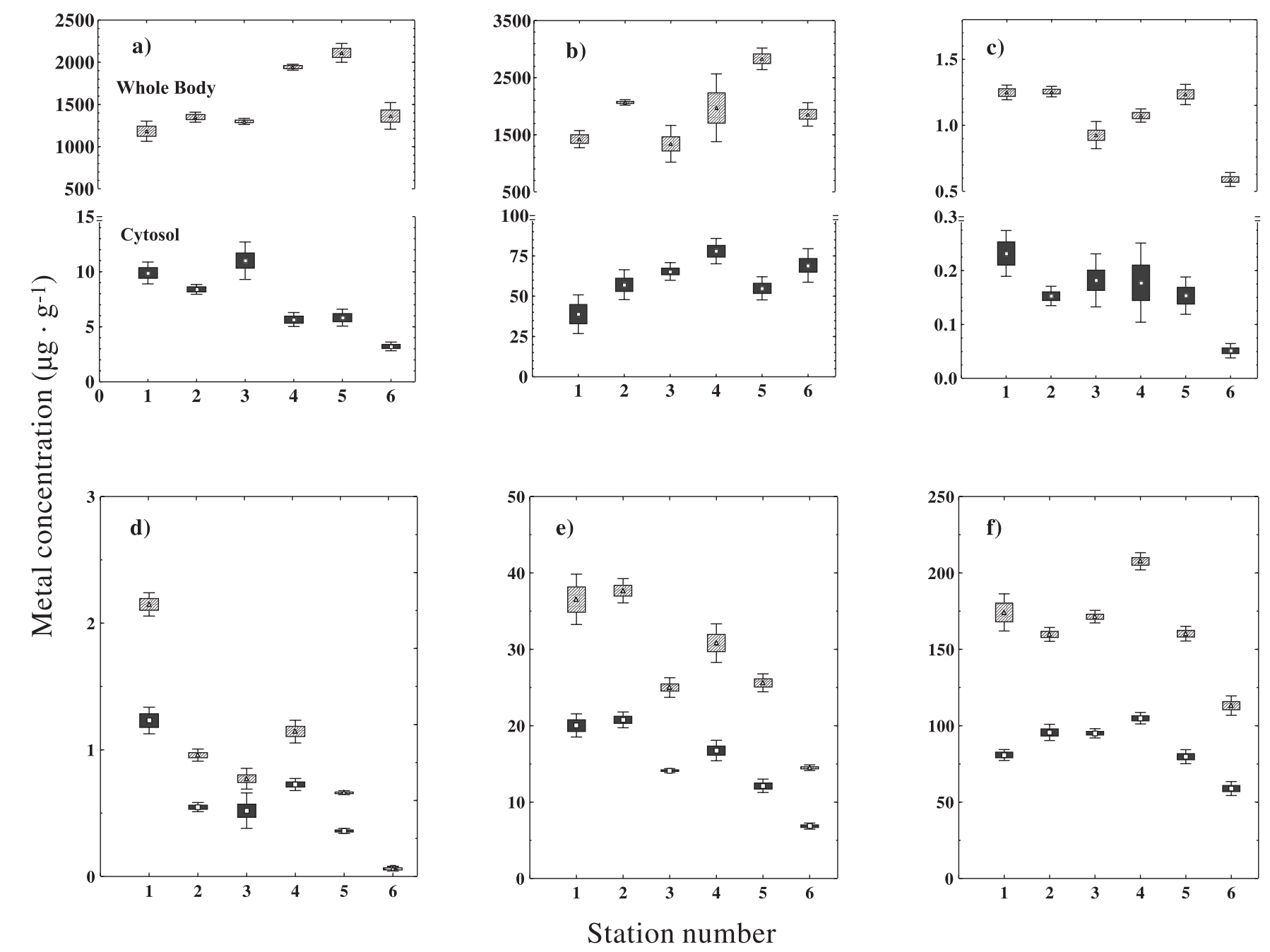

that of Fe. Mercury concentrations in samples collected from the Sacramento River were slightly less than in the Cottonwood Creek sample and did not exhibit any organized spatial pattern (Table 1).

\section{Spatial patterns in enriched, cytosolic metals}

Cytosolic metals differed in their distribution in the Sacramento River. Maximum concentrations of cytosolic $\mathrm{Cd}, \mathrm{Cu}$, $\mathrm{Pb}$, and $\mathrm{Al}$ occurred in the samples from the three most upstream stations (Rodeo Park, Churn Creek, and Balls Ferry). From these stations, cytosolic metal concentrations decreased downstream to Tehama, although the attenuation patterns differed in some respects. Cadmium displayed the greatest attenuation in concentration, decreasing about $70 \%$ from Rodeo Park to Tehama. The majority (80\%) of this decrease occurred between Rodeo Park and Churn Creek (Fig. 3). Copper concentrations decreased by roughly $40 \%$ between Rodeo Park and Tehama. Concentrations were similar at Rodeo Park and Churn Creek and then decreased significantly at Balls Ferry. Between Balls Ferry and Tehama, $\mathrm{Cd}$ and $\mathrm{Cu}$ concentrations followed one another closely. A small, but significant increase in concentrations occurred at Bend Bridge; then, concentrations decreased at Tehama. Lead concentrations were not significantly different among stations in the Sacramento River, although concentrations decreased by $40 \%$ between Rodeo Park and Churn Creek. Cytosolic Al concentrations ranged between 8 and $11 \mu \mathrm{g} \cdot \mathrm{g}^{-1}$ in the reach between Rodeo Park and Balls Ferry and then declined significantly to $6 \mu \mathrm{g} \cdot \mathrm{g}^{-1}$ at Bend Bridge and Tehama. The distribution pattern of $\mathrm{Zn}$ contrasted with that of the other metals. Zinc concentrations at Rodeo Park and Tehama were the same and significantly lower than concentrations at Churn Creek, Balls Ferry, and Bend Bridge.

\section{Metal concentrations in sediments and relationships with Hydropsyche}

Concentrations of $\mathrm{Cd}, \mathrm{Cu}, \mathrm{Hg}, \mathrm{Pb}$, and $\mathrm{Zn}$ in streambed sediments $(<62 \mu \mathrm{m})$ were typically greater in the Sacramento River than in Cottonwood Creek (Table 3). The maximum concentrations of $\mathrm{Cd}, \mathrm{Cu}, \mathrm{Hg}$, and $\mathrm{Zn}$ at Churn Creek were three to nine times greater than concentrations in Cottonwood Creek, and enrichment of these metals was still evi- 


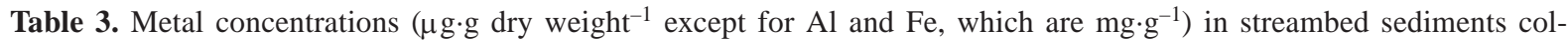
lected from the Sacramento River and Cottonwood Creek during October 21-23, 1996.

\begin{tabular}{lcccccc}
\hline & \multicolumn{5}{l}{ Station } \\
\cline { 2 - 6 } Element & 1 (Rodeo Park) & 2 (Churn Creek) & 3 (Balls Ferry) & 4 (Bend Bridge) & 5 (Tehama) & 6 (Cottonwood Creek) \\
\hline $\mathrm{Al}$ & $76 \pm 0$ & $67 \pm 1$ & $84 \pm 2$ & $75 \pm 2$ & $58 \pm 2$ & $70 \pm 0$ \\
$\mathrm{Cd}$ & $2.7 \pm 0$ & $3.6 \pm 0.2$ & $1.5 \pm 0.1$ & $0.9 \pm 0.2$ & $1.3 \pm 0.1$ & $0.4 \pm 0$ \\
$\mathrm{Cu}$ & $240 \pm 10$ & $250 \pm 0$ & $100 \pm 0$ & $75 \pm 2$ & $78 \pm 2$ & $61 \pm 2$ \\
$\mathrm{Fe}$ & $56 \pm 1$ & $56 \pm 2$ & $61 \pm 2$ & $49 \pm 2$ & $48 \pm 2$ & $50 \pm 2$ \\
$\mathrm{Hg}$ & $0.40 \pm 0.01$ & $0.39 \pm 0$ & $0.15 \pm 0.01$ & $0.08 \pm 0$ & $0.25 \pm 0.02$ & $0.06 \pm 0.01$ \\
$\mathrm{~Pb}$ & $36 \pm 2$ & $36 \pm 1$ & $24 \pm 0$ & $14 \pm 1$ & $14 \pm 1$ & $14 \pm 0$ \\
$\mathrm{Zn}$ & $410 \pm 10$ & $550 \pm 20$ & $310 \pm 10$ & $220 \pm 10$ & $230 \pm 10$ & $110 \pm 0$ \\
\hline
\end{tabular}

Note: Values are the mean $\pm 1 \mathrm{SD}(n=3)$.

Table 4. Pearson product-moment correlation coefficients $r$ shown for correlations between sediments and $H$. californica (whole body and cytosol) collected from the Sacramento River and Cottonwood Creek during October 21-23, 1996.

\begin{tabular}{lll}
\hline & \multicolumn{2}{l}{ Correlation coefficient $r$} \\
\cline { 2 - 3 } Element & Sediment $\times$ whole body & Sediment $\times$ cytosol \\
\hline $\mathrm{Al}$ & -0.57 & 0.57 \\
$\mathrm{Cd}$ & 0.51 & 0.46 \\
$\mathrm{Cu}$ & $0.83^{*}$ & $0.84^{*}$ \\
$\mathrm{Fe}$ & -0.75 & -0.31 \\
$\mathrm{Hg}$ & -0.31 & - \\
$\mathrm{Pb}$ & 0.54 & 0.56 \\
$\mathrm{Zn}$ & 0.26 & 0.50 \\
\hline
\end{tabular}

Note: The mean metal concentrations from all stations were used in the analysis. Significant correlations $(p<0.05)$ are indicated with an asterisk.

dent in sediment at Tehama. Compared with those metals, $\mathrm{Pb}$ was less enriched in Sacramento River sediment (maximum concentrations were about twice as high as in Cottonwood Creek sediment), and enrichment did not appear to extend further downstream than Balls Ferry. The mean concentrations of $\mathrm{Cd}, \mathrm{Cu}, \mathrm{Hg}, \mathrm{Pb}$, and $\mathrm{Zn}$ among all stations correlated significantly (results not shown), reflecting the overall decrease in concentrations from upstream to downstream (Table 3).

Aluminum and Fe in streambed sediments of the Sacramento River were not clearly enriched relative to those in Cottonwood Creek sediment (Table 3). For both elements, the lowest concentrations occurred at Tehama and the highest concentrations occurred at Balls Ferry; however, the mean concentrations among all stations were not significantly correlated.

With the exception of $\mathrm{Cu}$, correlations between metal concentrations in streambed sediments and Hydropsyche were insignificant (Table 4). Most metals that were enriched in sediments were also enriched in Hydropsyche, and downstream attenuation in the concentrations of $\mathrm{Cd}, \mathrm{Cu}$, and $\mathrm{Pb}$ occurred in both sediments and the insect. However, the spatial distributions of $\mathrm{Cd}$ and $\mathrm{Pb}$ differed in some respects between the sample types, affecting the correlations. Spatial patterns for $\mathrm{Cd}$ in sediments and Hydropsyche were fairly similar, except that maximum $\mathrm{Cd}$ concentrations in sediments and the insect occurred at adjacent stations: the former at Churn Creek and the latter at Rodeo Park (Tables 1 and 3). Lead contamination of sediments was only evident between Rodeo Park and Bend Bridge, a distance of about $60 \mathrm{~km}$, whereas cytosolic concentrations in Hydropsyche at Tehama indicated that contamination of bioavailable $\mathrm{Pb}$ extended at least $111 \mathrm{~km}$ downriver. Concentrations of $\mathrm{Hg}$ and $\mathrm{Zn}$ in sediments and the insect were generally inconsistent. Mercury contamination, evident in sediments, was not observed in Hydropsyche. Unlike the sediments, cytosolic (and whole-body) Zn did not decrease downstream, although concentrations in samples from all five Sacramento River stations were significantly higher than in the sample from Cottonwood Creek.

\section{Discussion}

Metal concentrations in Hydropsyche and streambed sediment samples taken in October 1996 from the Sacramento River indicate that metal contamination occurs between Redding (Rodeo Park) and Tehama $(368 \mathrm{~km}$ from river mouth), which is approximately $120 \mathrm{~km}$ downstream of the Keswick Dam. Furthermore, analysis of metal accumulation in the cytosol of Hydropsyche verified that this contamination includes biologically available $\mathrm{Cd}, \mathrm{Cu}, \mathrm{Pb}$, and $\mathrm{Zn}$. Mercury contamination was evident in streambed sediments but not in Hydropsyche.

Metal partitioning patterns were indicative of the location and form of metal within the animal and thus provided some insight into accumulation processes. Differences in the partitioning of different metals between the cytosol and particulate (pellet) fractions in our study were consistent with results reported by Cain and Luoma (1998) for the same genus. Most of the $\mathrm{Al}, \mathrm{Fe}$, and $\mathrm{Pb}$ in Hydropsyche was present in a particulate form(s). Although the pellet was not further characterized, its content would include the exoskeleton, undigested gut content, cell membranes, larger intracellular organelles, and insoluble intracellular granules. Other studies have suggested that substantial amounts of $\mathrm{Al}, \mathrm{Fe}$, and $\mathrm{Pb}$ can be sorbed to external body surfaces (Krantzberg and Stokes 1988; Hare et al. 1991; Cain et al. 1992). In undepurated animals, variable amounts of metals are also associated with undigested gut content (Smock 1983; Hare et al. 1989; Cain et al. 1995). Thus, it is likely that much of the $\mathrm{Al}, \mathrm{Fe}$, and $\mathrm{Pb}$ could be characterized as extracellular. Similarities in the spatial patterns of noncytosolic, particulate $\mathrm{Al}$, $\mathrm{Fe}$, and $\mathrm{Pb}$, particularly downstream of Balls Ferry, suggest that accumulation occurred by similar processes, possibly by sorption to external body parts and (or) inadvertent ingestion of sediment. There was no correspondence between concen- 
trations of $\mathrm{Al}$ and $\mathrm{Fe}$ in the particulate fraction (and whole body) and in the cytosol. A small proportion (8-20\%) of the $\mathrm{Pb}$ body burden was recovered in the cytosol. Whole-body concentrations of $\mathrm{Pb}$ were generally indicative of differences in cytosolic $\mathrm{Pb}$ between uncontaminated (Cottonwood Creek) and contaminated (Sacramento River) samples but not among samples in the Sacramento River. It is possible that the relatively narrow range of low concentrations in the Sacramento River influenced the relationship. Significant correlations between whole-body and cytosolic $\mathrm{Pb}$ have been observed where $\mathrm{Pb}$ contamination is greater than in the Sacramento River (Cain and Luoma 1998). In contrast with $\mathrm{Al}, \mathrm{Fe}$, and $\mathrm{Pb}$, a large portion of the total $\mathrm{Cd}, \mathrm{Cu}$, and $\mathrm{Zn}$ occurred in the cytosol, which explains the high degree of correspondence between cytosolic and whole-body concentrations for these elements.

The sampling design was not able to either isolate the source of metal or completely delineate the downstream extent of contamination. However, the spatial patterns of $\mathrm{Cd}$, $\mathrm{Cu}$, and $\mathrm{Pb}$ in Hydropsyche are consistent with documented inputs of dissolved and particulate-bound metals from mineralized areas upstream of Keswick Reservoir (Nordstrom et al. 1977). Inputs of metals from Keswick Reservoir increase during winter high river flow, creating a seasonal gradient in dissolved and suspended particulate concentrations (Alpers et al. 1999). Metal inputs appear to be preserved in streambed sediments because concentration gradients were evident in sediments downstream of Keswick Reservoir in October. Thus, streambed sediments and Hydropsyche were basically consistent in characterizing $\mathrm{Cd}, \mathrm{Cu}$, and $\mathrm{Pb}$ contamination in the Sacramento River.

Inconsistencies between environmental (e.g., sediments) and biological indicators can arise from both abiotic and biotic causes. In this study, metal concentrations in sediments were determined for total sediment digestions, which may not provide reliable estimates of bioavailable metal. Furthermore, exposure pathways for Hydropsyche, a filter-feeder, are probably more closely related to metal concentrations in water and food in suspended material than to those in bed sediments. Physiological processes also influence metal concentrations and distributions in the organism. Relationships between metal concentrations in streambed sediments and Hydropsyche were generally not statistically significant, $\mathrm{Cu}$ being the only exception. As discussed above, both sediments and Hydropsyche exhibited concentration gradients for $\mathrm{Cd}$ and $\mathrm{Pb}$ in the Sacramento River. However, the features of those gradients differed between the sample types, affecting the correlations. For $\mathrm{Al}, \mathrm{Hg}$, and $\mathrm{Zn}$, the differences were more basic. While neither sedimentary nor whole-body Al concentrations exhibited any obvious contamination, cytosolic Al suggested increased exposure to bioavailable Al between Rodeo Park and Balls Ferry. However, Al concentrations in the cytosol were very low relative to the whole body, and it is possible that the cytosolic concentrations reflect some low-level contamination of the cytosol by particulate Al during the preparation of the sample. Mercury concentrations in streambed sediments were elevated in the upper Sacramento River relative to Cottonwood Creek. However, concentrations in Hydropsyche were $<0.1 \mu \mathrm{g} \cdot \mathrm{g}^{-1}$ at all stations, which appears to be indicative of background concentrations for the Sacramento River watershed (Slotton et al. 1997). Mercury contributions from the upstream acid mine drainage site (Iron Mountain via Spring Creek) are apparently not a major source to the river. Dissolved $\mathrm{Hg}$ concentrations in the Sacramento River are low $\left(<0.4-2.2 \mathrm{ng} \cdot \mathrm{L}^{-1}\right)$. The majority of $\mathrm{Hg}$ in suspension occurs with colloids in oxidizable and residual (mineral) phases (Alpers et al. 1999). Evidently, these sources are not sufficient to cause $\mathrm{Hg}$ enrichment in Hydropsyche. Inconsistencies between $\mathrm{Zn}$ concentrations in bed sediments $(<62 \mu \mathrm{m})$ and in the cytosol of Hydropsyche observed in the Sacramento River have been observed in the Clark Fork River, also (Cain and Luoma 1998). Zinc accumulation in the cytosol reflected gross differences in contamination (e.g., between uncontaminated and contaminated sites) but was inconsistent with some environmental indicators of metal gradients (e.g., bed sediment concentrations). One explanation is that $\mathrm{Zn}$ uptake is relatively slow (Hare et al. 1991) and (or) that efflux of excess $\mathrm{Zn}$ from the cytosol is relatively rapid.

Metal exposures in Hydropsyche in the Sacramento River can be placed into context by comparison with rivers in other basins. A fairly extensive data set is available from the Clark Fork, a mining-impacted river in Montana. Over a 7-year period, annual $\mathrm{Cd}$ concentrations (whole body) in Hydropsyche sp. from the most heavily contaminated reach of the Clark Fork varied from approximately 1.5 to $3 \mu \mathrm{g} \cdot \mathrm{g}^{-1}$ (Hornberger et al. 1997). Cytosolic Cd concentrations in this same area ranged from approximately 0.25 to $1.5 \mu \mathrm{g} \cdot \mathrm{g}^{-1}$ (Cain and Luoma 1998). Some of the highest concentrations in the Clark Fork are similar to Cd concentrations at Rodeo Park near Redding $\left(2.16 \mu \mathrm{g} \cdot \mathrm{g}^{-1}\right.$ in the whole body and $1.27 \mu \mathrm{g} \cdot \mathrm{g}^{-1}$ in the cytosol). Concentrations of $\mathrm{Cu}, \mathrm{Pb}$, and $\mathrm{Zn}$ in the Sacramento River appear to be indicative of moderate contamination, relative to other studies (Cain et al. 1992; Hornberger et al. 1997). Metal concentrations in samples from Cottonwood Creek are characteristic of uncontaminated rivers (Cain et al. 1992; Fuhrer et al. 1994; Hornberger et al. 1997; Slotton et al. 1997).

High tissue concentrations can be symptomatic of toxic effects (Jarvinen and Ankley 1999). However, dose-response relationships are complex, and application of threshold concentrations observed in laboratory studies for a few test species to a natural population of a different species or to a whole community is prone to inherent uncertainty. Also, the effects of simultaneous, multiple-metal exposures that occur in nature are poorly understood. Nonetheless, the results for Cd seem pertinent to any future consideration of ecological risk in the upper Sacramento River. It is worth noting that tissue concentrations of $\mathrm{Cd}$ were comparable with concentrations in Hydropsyche in the upper Clark Fork River where metal exposure is considered a factor affecting changes in the composition and abundance of benthic macroinvertebrates (McGuire 1995). While Hydropsyche, a relatively metaltolerant organism (Spehar et al. 1978; Clements et al. 1992), might exhibit no obvious effect, more metal sensitive taxa could be affected. As in the Clark Fork (Cain and Luoma 1998), a large proportion ( $>50 \%$ ) of the Cd accumulated by Hydropsyche was associated with the cytosol. Because predators can efficiently assimilate cytosolic metals from their prey (Reinfelder and Fisher 1991, 1994; Wallace and Lopez 1997), food could be an important source of Cd to higher trophic animals such as fish. 


\section{Conclusions}

Comparison of metals accumulated in the whole body and the cytosol of caddisfly larvae facilitated interpretations of the metal exposures, relative to metal concentrations in streambed sediments, in the upper Sacramento River, downstream of Keswick Reservoir. Metal concentrations in the cytosol indicated exposure to elevated concentrations of bioavailable $\mathrm{Cd}, \mathrm{Cu}, \mathrm{Pb}$, and $\mathrm{Zn}$. Exposures, compared with a regional reference sample, were greatest for $\mathrm{Cd}$. The downstream concentration patterns indicated a primary upstream source of $\mathrm{Cd}, \mathrm{Cu}$, and $\mathrm{Pb}$ near or upstream from Redding (river $\mathrm{km}$ 479), consistent with concentration gradients in streambed sediments and documented inputs from Iron Mountain mine and Shasta Lake, which receives drainage from abandoned mining areas. The data did not delineate the downstream extent of general contamination and bioavailable metals; however, it was evident that bioavailable forms of these metals occurred downstream as far as Tehama (river $\mathrm{km} \mathrm{368),}$ $120 \mathrm{~km}$ downstream of the Keswick Dam.

\section{Acknowledgements}

We thank Terry Short, Marc Sylvester, and Roger Hothem for their comments on an earlier version of this paper. Arthur Horowitz and Kent Elrick conducted the $\mathrm{Hg}$ determinations on $H$. californica. Jill Marshall assisted with sample collection.

\section{References}

Alpers, C.N., Taylor, H.E., and Domagalski, J.L. (Editors). 1999. Metals transport in the Sacramento River, California, 1996-1997. Vol. 1. Methods and data. U.S. Geol. Surv., Water-Resources Investigations Report 99-4286.

Cain, D.J., and Luoma, S.N. 1998. Metal exposures to native populations of the caddisfly Hydropsyche (Trichoptera: Hydropsychidae) determined from cytosolic and whole body metal exposures. Hydrobiologia, 386: 103-117.

Cain, D.J., Luoma, S.N., Carter, J.L., and Fend, S.V. 1992. Aquatic insects as bioindicators of trace element contamination in cobblebottom rivers and streams. Can. J. Fish. Aquat. Sci. 49: 21412154.

Cain, D.J., Luoma, S.N., and Axtmann, E.V. 1995. Influence of gut content in immature aquatic insects on assessments of environmental metal contamination. Can. J. Fish. Aquat. Sci. 52: 2736-2746.

Clements, W.H., Cherry, D.S., and Van Hassel, J.H. 1992. Assessment of the impact of heavy metals on benthic communities at the Clinch River (Virginia): evaluation of an index of community sensitivity. Can. J. Fish. Aquat. Sci. 49: 1686-1694.

Elrick, K.A., and Horowitz, A.J. 1986. Analysis of rocks and sediments for mercury, by wet digestion and flameless cold vapor atomic absorption. U.S. Geol. Surv. Open File Rep. 86-529.

Farag, A.M., Stansbury, M.A., Hogstrand, C., MacConnell, E., and Bergman, H.L. 1995. The physiological impairment of free-ranging trout exposed to metals in the Clark Fork River, Montana. Can. J. Fish. Aquat. Sci. 52: 2038-2050.

Finlayson, B., and Verrue, K. 1980. Estimated safe zinc and copper levels for chinook salmon, Oncoryhnchus tshawytscha, in the Upper Sacramento River, California. Calif. Fish Game, 66: 68-82.

Fuhrer, G.J., Fluter, S.L., McKenzie, S.W., Rinella, J.F., Crawford, J.K., Cain, D.J., Hornberger, M.I., Bridges, J.L., and Sach, K.A. 1994. Surface-water-quality assessment of the Yakima River Basin in Washington: major- and minor-element data for sediment, water, and aquatic biota, 1987-91. U.S. Geol. Surv. Open File Rep. 94-308.

Hare, L. 1992. Aquatic insects and trace metals: bioavailability, bioaccumulation and toxicity. Crit. Rev. Toxicol. 22: 327-369.

Hare, L., Campbell, P.G.C., Tessier, A., and Belzile, N. 1989. Gut sediments in a burrowing mayfly (Ephemeroptera: Hexagenia limbata): their contribution to animal trace element burdens, their removal, and the efficacy of a correction for their presence. Can. J. Fish. Aquat. Sci. 46: 451-456.

Hare, L., Saouter, E., Campbell, P.G.C., Tessier, A., Ribeyre, F., and Boudou, A. 1991. Dynamics of cadmium, lead, and zinc exchange between nymphs of the burrowing mayfly Hexagenia rigida (Ephemeroptera) and the environment. Can. J. Fish. Aquat. Sci. 48: 39-47.

Hornberger, M.I., Lambing, J.H., Luoma, S.N., Axtmann, E.V. 1997. Spatial and temporal trends in trace metals in water, bed sediment, and biota of the upper Clark Fork River basin, Montana: 1985-1995. U.S. Geol. Surv. Open File Rep. 97-669.

Jarvinen, A.W., and Ankley, G.T. 1999. Linkage of effects to tissue residues: development of a comprehensive database for aquatic organisms exposed to inorganic and organic chemicals. Society of Environmental Toxicology and Chemistry (SETAC) Technical Publication Series, Pensicola, Fla.

Jenkins, K.D., and Mason, A.Z. 1988. Relationships between subcellular distributions of cadmium and perturbations in reproduction in the polycheate Neanthes arenaceodentata. Aquat. Toxicol. 12: 229-244.

Krantzberg, G., and Stokes, P.M. 1988. The importance of surface absorption and $\mathrm{pH}$ in metal accumulation in chironomids. Environ. Toxicol. Chem. 7: 653-670.

Lee, B.-G., and Luoma, S.N. 1998. Influence of microalgal biomass on absorption efficiency of $\mathrm{Cd}, \mathrm{Cr}$, and $\mathrm{Zn}$ by two bivalves in San Francisco Bay. Limnol. Oceanogr. 43: 1455-1466.

McGuire, D.L. 1995. Clark Fork River macroinvertebrate community biointegrity: 1993 assessment. Montana Department of Health and Environmental Sciences Water Quality Bureau, Helena, Mt.

Moore, J.N., and Luoma, S.N. 1990. Hazardous waste from largescale metal extraction. Environ. Sci. Technol. 24: 1279-1285.

National Oceanic and Atmospheric Administration. 1989. Preliminary natural resource survey, Iron Mountain mine: findings of fact. National Oceanic and Atmospheric Administration, Washington, D.C.

National Oceanic and Atmospheric Administration. 1994. Endangered and threatened species; status of Sacramento River winterrun chinook salmon. Federal Register, 59: 440-450.

National Oceanic and Atmospheric Administration. 1997. Endangered and threatened species; listing of several evolutionarily significant units of west coast steelhead. Federal Register, 62: 43937.

Nordstrom, D.K., Jenne, E.A., and Averett, R.C. 1977. Heavy metal discharges into Shasta Lake and Keswick Reservoir on the Upper Sacramento River, California: a reconnaissance during low flow. U.S. Geol. Surv. Open File Rep. 76-49.

Nott, J.A., and Nicolaidou, A. 1990. Transfer of metal detoxification along marine food chains. J. Mar. Biol. Assoc. U.K. 70: 905-912.

Reinfelder, J.R., and Fisher, N.S. 1991. The assimilation of elements ingested by marine copepods. Science (Washington, D.C.), 251: 794-796.

Reinfelder, J.R., and Fisher, N.S. 1994. Retention of elements absorbed by juvenile fish (Menidia menidia, Menidia beryllina) from zooplankton prey. Limnol. Oceanogr. 39: 1783-1789.

Roesijadi, G. 1994. Behavior of metallothionein-bound metals in a natural population of an estuarine mollusc. Mar. Environ. Res. 38: $47-168$. 
Rosenberg, D.M., and Resh, V.R. (Editors). 1993. Freshwater biomonitoring and benthic macroinvertebrates. Chapman and Hall, New York.

Roth, D.A. 1994. Ultratrace analysis of mercury and its distribution in some natural waters of the United States. Ph.D. thesis, Colorado State University, Fort Collins, Co.

Saiki, M.K., Castleberry, D.T., May, T.W., Martin, B.A., and Bullard, F.N. 1995. Copper, cadmium, and zinc concentrations in aquatic food chains from the upper Sacramento River (California) and selected tributaries. Arch. Environm. Contam. Toxicol. 29: 484-491.

Seidman, L.A., Bergtron, G., Gingrich, D.J., and Remsen, C.C. 1986. Accumulation of cadmium by the fourth instar larva of the fly Chironomus thummi. Tissue Cell, 18: 395-405.

Shelton, L.R., and Capel, P.D. 1994. Guideline for collecting and processing samples of stream bed sediment for analysis of trace elements and organic contaminants for the National Water Quality Assessment Program. U.S. Geol. Surv. Open File Rep. 94-458.

Slotton, D.G, Ayers, S.M., Rueter, J.E., and Goldman, C.R. 1997. Gold mining impacts on food chain mercury in northwestern Sierra Nevada streams, final report. University of California Water Resources Center and the Sacramento Regional County Sanitation District, Sacramento, Calif.

Smock, L.A. 1983. The influence of feeding habits on whole-body metal concentrations in aquatic insects. Freshwater Biol. 13: 301-311.

Spehar, R.L., Anderson, R.L., and Fiandt, J.T. 1978. Toxicity and bioaccumulation of cadmium and lead in aquatic invertebrates. Environ. Pollut. 15: 195-208.

Suzuki, K.T., Sunaga, H., Aoki, Y., Hatakeyama, S., Sugaya, Y., Sumi, Y., and Suzuki, T. 1988. Binding of cadmium and copper in the mayfly Baetis thermicus larvae that inhabit a river pol- luted with heavy metals. Comp. Biochem. Physiol. C. Comp. Pharmacol. Toxicol. 91: 487-492.

Taylor, H.E., and Garbarino, J.R. 1985. Recent developments and applications of inductively coupled plasma emission spectroscopy to trace elemental analysis of water. In Trace analysis. Vol. 4. Academic Press, Inc., New York. pp. 185-236.

Taylor, H.E., and Garbarino, J.R. 1991. The measurement of trace metals in water resources monitoring samples by inductively coupled plasma - mass spectrometry. Spectrochim. Acta Rev. 4: 33-43.

Thorpe, G.J., and Costlow, J.D. 1989. The relation of the acute (96-h) uptake and subcellular distribution of cadmium and zinc to cadmium toxicology in larvae of Rhithropanopeus harrisii and Palaemontes pugio. In Aquatic toxicology and hazard assessment. Vol. 12. Edited by U.M. Cowgill and L.R. Williams. American Society for Testing and Materials, Philadelphia, Pa. pp. 82-94.

U.S. Environmental Protection Agency. 1992. Public comment environmental endangerment assessment, Iron Mountain mine, Redding, California. EPA WA No. 31-01-9N17 under contract 68-W9-0031. Prepared by CH2M-Hill, Redding, Calif.

Wallace, W.G., and Lopez, G.R. 1997. Bioavailability of biologically sequestered cadmium and the implications of metal detoxification. Mar. Ecol. Prog. Ser. 147: 149-157.

Wilson, D.B., Finlayson, B., and Morgan, N. 1981. Copper, zinc, and cadmium concentrations of resident trout related to acidmine wastes. Calif. Fish Game, 67:176-186.

Woodward, D.F., Farag, A.M., Bergman, H.L., DeLonay, A.J., Little, E.E., Smith, C.E., and Barrows, F.T. 1995. Metals-contaminated benthic invertebrates in the Clark Fork River, Montana: effects on age-0 brown trout and rainbow trout. Can. J. Fish. Aquat. Sci. 52: 1994-2004. 